Génét. Sél. Evol., 1988, 20 (4), 499-510

\title{
Thyroid hormones and antibody response to sheep erythrocytes of dwarf and normal chickens selected for juvenile body weight
}

\author{
A. MARTIN, F.M.A. McNABB and P.B. SIEGEL \\ Virginia Polytechnic Institute and State University, \\ Blacksburg, Virginia 24061, USA
}

\begin{abstract}
Summary
Experiments were conducted in lines of chickens selected for high $(H W)$ and low $(L W)$ body weight to determine effects of dosage of antigen, line, sex-linked dwarfism, and plasma thyroid hormone concentrations on antibody titers to sheep red blood cells (SRBC). The greatest separation of lines and of dwarf-normal genotypes occurred with an intermediate dose $(0.1 \mathrm{ml}$ of $0.25 \%$ ) of SRBC. Five days after administration of SRBC at this dose antibody responses were greater for line $L W$ than $H W$ and in dwarf than normal chicks. The dwarf-normal but not the line relationship was evident for the booster challenge as well. Separation of lines and dwarf-normal genotypes for plasma thyroid hormone concentrations was greater at 71 than 36 days of age. Also the effect of the dwarfing allele on thyroid hormones was dependent on the background genome. There was no relationship between plasma triiodothyronine $\left(\mathrm{T}_{3}\right)$ and thyroxine $\left(\mathrm{T}_{4}\right)$ concentrations and antibody responses to SRBC. These data do not support the suggestions of a relationship between antibodies to SRBC and plasma $T_{3}$ and $T_{4}$.
\end{abstract}

Key words : chicken, dwarf, triiodothyronine $\left(T_{3}\right)$, thyroxine $\left(T_{4}\right)$, genetics.

\section{Résumé}

Hormones thyroüdiennes et production d'anticorps contre des érythrocytes de mouton chez des poulets nains et normaux sélectionnés pour leur poids corporel juvénile

Nous avons effectué des expériences sur des lignées de poulets sélectionnés pour leur poids corporel haut $(H W)$ ou bas $(L W)$ en vue de déterminer les effets du dosage d'antigène, de la lignée, du nanisme lié au sexe et des concentrations sanguines des hormones thyrö̈diennes sur les anticorps aux globules rouges de mouton (SRBC). Les plus grandes séparations entre lignées et entre génotypes nains-normaux se sont produites avec un dosage intermédiaire $(0,1 \mathrm{ml}$ de $0,25 \%$ de SRBC). Cinq jours après l'administration de SRBC à ce dosage, les réponses anticorporelles étaient plus élevées dans la lignée $L W$ que dans la lignée $H W$, et chez les nains que chez les normaux. La relation entre nains et normaux était évidente dans la réponse secondaire aussi. La séparation des lignées et des génotypes nain-normal vis-à-vis des concentrations des hormones thyroïdiennes était plus grande à 71 qu'à 36 jours d'âge. Par ailleurs, l'effet du gène de nanisme sur les hormones thyrö̈diennes était dépendant de l'environnement génomique. Il n'y avait aucune relation entre les concentrations sanguines de triiodothyronine $\left(T_{3}\right)$ ou de thyroxine $\left(T_{4}\right)$ et la réponse anticorporelle à SRBC. Ces données ne confirment pas l'hypothèse d'une relation entre anticorps à SRBC et concentrations de $T_{3}$ et $T_{4}$.

Mots clés : poulet, nanisme, triiodothyronine $\left(T_{3}\right)$, thyroxine $\left(T_{4}\right)$, génétique. 


\section{Introduction}

The effect of the sex-linked allele $d w$ on immunoresponsiveness of chickens to sheep erythrocyte antigen (SRBC) appears variable (MARSH, 1983 ; LiLBURN et al., $1986 \mathrm{~b}$ ). Although lower antibody levels were observed for dwarf than nondwarf White Leghorns (MARSH, 1983), there were no differences in meat-type chickens (LILBURN et $a l ., 1986 \mathrm{~b}$ ). This inconsistency implies that effects of the dwarfing allele on responses to SRBC may be, as with other traits, dependent upon the background genome (MAUldin et al., 1978 ; MÉrat, 1982 ; Lilburn et al., 1986 a).

Lower antibody titers to SRBC in sex-linked dwarf than in autosomal dwarf or normal Leghorns (MARSH, 1983) have been attributed to differences in serum concentrations of thyroid hormones (MARSH, 1983 ; GuICK, 1984). This reasoning was consistent with findings that sex-linked dwarfs were functionally hypothyroid due to lower conversion rates of $\mathrm{T}_{4}$ to $\mathrm{T}_{3}$ (MAY \& MARKS, 1983 ; ScANes et al., 1983 ; MARSH et al., $1984 a) ; \mathrm{T}_{3}$ is thought to be the metabolically active hormone in birds (see review in McNABB, 1987).

The following experiments were conducted to further explore the influence of $d w$ on antibody response to SRBC in lines of chickens selected for high and low juvenile body weight, and to evaluate the possible relationship with plasma thyroid hormone concentrations.

\section{Materials and methods}

Chickens from six populations, $H W N, L W N, H W D, L W D, H A$ and $L A$ were used in this experiment. $H W N$ and $L W N$ were lines of nondwarf White Plymouth Rocks which had undergone individual phenotypic selection for high $(H W)$ and for low $(L W)$ body weight at 56 days of age (Siegel, 1962 ; DunNington \& Siegel, 1985). In the $S_{13}$ generation the sex-linked dwarfing allele $(d w)$ was introduced into these lines by mating $D w^{+} / d w$ males of a meat-type stock to a random sample of females from each line (REDDY et al., 1975). High weight dwarf (HWD) and low weight dwarf (LWD) populations were then developed through repeated backcrossing of $D w^{+} / d w$ males to normal $H W$ and $L W$ females. After 10 generations of backcrossing the $H W D$ and $L W D$ populations were reproduced each generation by random mating of dwarf males and females within each population as contemporaries of the selected lines.

Lines $H A$ and $L A$ served as reference populations. These nondwarf lines of White Leghorns had undergone 14 generations of selection for high $(H A)$ and low (LA) antibody response five days post intravenous (IV) inoculation with $0.1 \mathrm{ml}$ of $0.25 \%$ suspension of sheep erythrocytes (SIEGEL \& Gross, 1980). In the following experiments antigen was inoculated intravenously (IV) into the brachial vein and blood samples were taken from this vein. Lines $H A$ and $L A$ do not differ in thyroxine levels at 42 days of age, but tri-iodothyronine levels are higher for line $H A$ than $L A$ (MARTIN et al., 1987). 


\section{A. Experiment I}

Chicks used in this experiment were a random sample of males from generation 29 of populations $H W N$ and $L W N$ and generation 16 of the $H W D$ and $L W D$ sublines. All chicks were vaccinated at hatch against Marek's disease and reared as contemporaries in floor pens. Food, water and light were provided constantly throughout the experiment.

The test immunogen used in these experiments was sheep red blood cells (SRBC), a T-cell dependent antigen in chickens. At 66 days of age $0.1 \mathrm{ml}$ of either $0.025,0.25$, or $25 \%$ suspension of SRBC in physiological saline was injected IV into $H W N, L W N$, $H W D$ and $L W D$ chicks. There were 12 chicks per line-dosage subclass. Blood samples were collected from the brachial vein 5 and 12 days post primary inoculation (PPI). Experiments on the kinetics of response using these procedures showed that peak titers occurred five days PPI (UBosi et al., 1985 b). Plasma antibody to SRBC was determined by microtitration method (WEGMANN \& SMITHIEs, 1966), and titers are expressed as $\log _{2}$ of the reciprocal of the highest dilution in which there was agglutination.

Secondary IV inoculations were given 24 days after primary inoculation to half of the chicks from each of the above populations. The booster dosage was $0.1 \mathrm{ml}$ of $0.25 \%$ suspension of SRBC and chicks were bled three days post secondary inoculation (PSI). Previous studies (UBosi et al., $1985 \mathrm{~b}$ ) with these procedures showed peak titers occurred at this time.

Twelve $H A$ and $12 L A$ males served as a benchmark against which the titers of the above males could be related. Each was inoculated intravenously with $0.1 \mathrm{ml}$ of $0.25 \%$ SRBC at 52 days of age (the same day as the primary inoculation for the others), and were bled at the same time as the above males. Half were given the booster inoculation as well.

\section{B. Experiment II}

Chicks used in this experiment were from generation 30 of the $H W N$ and $L W N$ populations and from generation 17 of the $H W D$ and $L W D$ populations. Male and female chicks from age contemporary parents were vaccinated for Marek's disease at hatch and reared in wire brooder pens. As in Experiment I, feed and water were provided ad libitum and lighting was continuous.

Chicks were randomly divided into two groups at hatch. One group was inoculated intravenously with SRBC at 31 days of age, the other at 66 days of age. All chicks received $0.1 \mathrm{ml}$ of $0.25 \%$ suspension of SRBC, the optimal dosage for discerning genetic differences in Experiment I. Blood was drawn five days PPI (at 36 and 71 days of age, respectively) for determination of SRBC antibody titers and plasma concentrations of triiodothyronine $\left(\mathrm{T}_{3}\right)$ and thyroxine $\left(\mathrm{T}_{4}\right)$. Antibody titers were assayed as in Experiment $I$. Concentrations of $T_{3}$ and $T_{4}$ were determined by double antibody radioimmunoassay procedures verified for use on avian plasma (McNABB \& HugHes, 1983). Respective sample sizes of inoculated $H W N, H W D, L W N$, and $L W D$ chicks were $31,35,27$, and 21 at the younger, and $26,35,21$, and 17 chicks at the older age. 


\section{Statistical analysis}

Differences discussed in the text were considered statistically significant at $P<0.05$. In Experiment I, analysis of variance was conducted on antibody titers within days PPI or PSI to determine the effects of line, dosage, genotype, and interactions among these variables. The statistical model used was :

$$
\mathrm{Y}_{i j k l}=\mu+\mathrm{L}_{i}+\mathrm{D}_{j}+(\mathrm{LD})_{i j}+\mathrm{G}_{k}+(\mathrm{LG})_{i k}+(\mathrm{DG})_{j k}+(\mathrm{LDG})_{i j k}+\mathrm{e}_{i j k l}
$$

where $i=H W$ and $L W$ lines, $j=1,2,3$ dosages and $k=D w^{+}$and $d w$ genotypes. Because means and variances were correlated for five day PPI titers at a $0.025 \%$ dose of SRBC, an analysis was conducted on theses values transformed to natural logarithms. Overall results from this analysis did not differ from that for untransformed values. When dosage effects were significant, analysis of variance were conducted within dosage to determine line, genotype, and line $\times$ genotype effects.

For Experiment II, analysis of variance showed no sexual dimorphism for any trait measured. Therefore sexes were pooled and effects of age, line, genotype, and their interactions were determined by analysis of variance for antibody titers, plasma $T_{3}$ and $T_{4}$ concentrations, and $T_{3} / T_{4}$ ratios. Where age was significant, analyses were conducted within ages to determine effects of line, genotype, and line $\times$ genotype interaction.

\section{Results}

In Experiment I, means and standard deviations for body weight (g) at 56 days of age were $1501 \pm 109$ and $905 \pm 97$ for $H W N$ and $H W D$ chicks, respectively, and $247 \pm 43$ and $309 \pm 54$ for $L W N$ and $L W D$ chicks, respectively. The magnitude of these differences is typical for these lines as selection was for high and low 56-day body weight (Dunnington \& SiEgel, 1985). The heavier weights for $L W D$ than for $L W N$ chickens were due to continuing selection for low body weight for the latter and relaxed selection for the former. Mean 56-day body weights of $H A$ and $L A$ chicks, respectively, were $526 \pm 100$ and $651 \pm 63$, an expected result because of the negative correlated response between antibody titer to SRBC and body weight (SIEGEL et al., 1982 ; VAN DER ZIJPP et al., 1987).

\section{A. SRBC Titers}

As expected, mean antibody titers for lines $H A$ and $L A$ using the $0.25 \%$ dosage of SRBC in Experiment I were different both PPI and PSI, and bracketed those for the other populations five days PPI (table 1). Thus, at this dose of antigen, responses of dwarf and normal $H W$ and $L W$ males were within the range of populations specifically selected for high and for low antibody response to SRBC antigen five days PPI.

Interactions of line and genotype with dosage were significant. The greatest separation among genotypes and lines was achieved using a $0.25 \%$ suspension of SRBC. Differences between genotypes were masked at the lower dose, while at the higher dose there was masking of all genetic differences. Primary and secondary SRBC 
TABLE 1

Means and standard deviations of antibody titers to sheep red blood cells for high (HW) and low (LW) body weight lines and for normal (N) and dwarf (dw) genotypes by antigen dose and days from primary (PPI) and secondary (PSI) inoculations

\begin{tabular}{|c|c|c|c|c|c|c|}
\hline \multirow{2}{*}{$\begin{array}{l}\text { Dose } \\
(\%)\end{array}$} & \multirow{2}{*}{ L } & \multirow{2}{*}{ G } & \multicolumn{3}{|c|}{ Days PPI } & \multirow{2}{*}{$\frac{\text { Days PSI }}{3}$} \\
\hline & & & 5 & 12 & 27 & \\
\hline \multirow[t]{2}{*}{0.025} & $H W$ & & $2.4 \underset{* *}{ \pm} 1.5$ & $0.6 \pm \underset{* *}{ \pm} 0.9$ & & $2.4 \pm 1.5$ \\
\hline & $L W$ & $\begin{array}{l}N \\
d w\end{array}$ & $\begin{array}{c}6.1 \pm 2.9 \\
3.8 \pm 2.4 \\
\mathrm{NS} \\
5.0 \pm 3.4\end{array}$ & $\begin{array}{c}2.3 \pm 1.6 \\
1.3 \pm 1.8 \\
\mathrm{NS} \\
1.7 \pm 1.2\end{array}$ & $\begin{array}{l}\text { see table } 2 \\
\text { for } \\
\text { Interactions }\end{array}$ & $\begin{array}{c}4.6 \pm 2.7 \\
2.4 \pm 1.2 \\
* \\
4.7 \pm 2.9\end{array}$ \\
\hline \multirow[t]{2}{*}{0.25} & $\begin{array}{l}H W \\
L W\end{array}$ & $N$ & $\begin{array}{c}4.8 \pm 2.7 \\
* * \\
10.3 \pm 3.4 \\
6.0 \pm 4.2 \\
* *\end{array}$ & $\begin{array}{l}\text { see table } 2 \\
\quad \text { for } \\
\text { Interactions }\end{array}$ & $\begin{array}{c}1.2 \pm 0.9 \\
* * \\
3.2 \pm 2.0 \\
1.7 \pm 1.8 \\
\text { NS }\end{array}$ & $\begin{array}{c}5.2 \pm 1.3 \\
\text { NS } \\
5.8 \pm 1.9 \\
4.8 \pm 1.1 \\
*\end{array}$ \\
\hline & $\begin{array}{l}H A^{(1)} \\
L A^{(1)}\end{array}$ & $d w$ & $\begin{array}{r}9.4 \pm 3.3 \\
12.4 \pm 1.8 \\
* * \\
4.0 \pm 2.2\end{array}$ & $\begin{array}{c}6.2 \pm 2.1 \\
* * \\
1.6 \pm 2.6\end{array}$ & $\begin{array}{c}2.8 \pm 1.8 \\
2.7 \pm 0.8 \\
* \\
1.0 \pm 1.1\end{array}$ & $\begin{array}{c}6.3 \pm 1.9 \\
5.8 \pm 2.1 \\
* \\
3.2 \pm 1.5\end{array}$ \\
\hline 25 & $\begin{array}{l}H W \\
L W\end{array}$ & $\begin{array}{l}N \\
d w\end{array}$ & $\begin{array}{c}13.2 \pm 1.8 \\
\mathrm{NS} \\
13.6 \pm 0.5 \\
13.2 \pm 1.6 \\
\mathrm{NS} \\
13.6 \pm 0.9\end{array}$ & $\begin{array}{l}\text { see table } 2 \\
\quad \text { for } \\
\text { Interactions }\end{array}$ & $\begin{array}{c}3.6 \pm 2.3 \\
\text { NS } \\
4.8 \pm 1.6 \\
4.1 \pm 2.0 \\
\text { NS } \\
4.5 \pm 2.1\end{array}$ & $\begin{array}{c}6.1 \pm 1.6 \\
\text { NS } \\
6.8 \pm 1.7 \\
6.0 \pm 1.8 \\
\text { NS } \\
7.0 \pm 1.4\end{array}$ \\
\hline
\end{tabular}

${ }^{*} \mathrm{P}<0.05,{ }^{* *} \mathrm{P}<0.01$, NS no significant difference $(\mathrm{P}>0.05)$.

$L=$ line, $G=$ genotype.

(1) Reference populations, selected for high (HA) or low (LA) antibody production to SRBC.

Boxes indicate significant line $\times$ genotype interactions (see table 2).

titers were reduced at the lower dose of antigen and elevated at the higher dose. The exception was that the secondary response of $L W D$ chicks did not differ with primary dosage level but was high for all dosages. Since differences between primary dosage groups existed for all SRBC titers, both PPI and PSI, results will be presented by dosage.

For the $0.025 \%$ dose of SRBC there were no line $\times$ genotype interactions for titers 5 and 12 days PPI, nor 3 days PSI (table 1). Titers were consistently lower for $H W$ than $L W$ chicks. Although there was no effect of dwarf genotype on antibody titers at either 5 or 12 days PPI, titers for dwarfs were higher than those for normals 3 days PSI. At 27 days PPI, the line $\times$ genotype interaction was significant. The interaction resulted from dwarfs having higher titers than normals in line $L W$ and no difference between genotypes in line $H W$ (table 2). 
TABLE 2

Means and standard deviations of antibody titers to sheep red blood cells for normal (N) and dwarf (dw) chickens within high (HW) and low (LW) body weight lines, by antigen dose and days from primary (PPI) and secondary (PSI) inoculations

\begin{tabular}{|c|c|c|c|c|c|c|}
\hline \multirow{2}{*}{$\begin{array}{c}\text { Dose } \\
(\%)\end{array}$} & \multirow{2}{*}{ L } & \multirow{2}{*}{ G } & \multicolumn{3}{|c|}{ Days PPI } & \multirow{2}{*}{$\begin{array}{c}\text { Days PSI } \\
3 \\
\end{array}$} \\
\hline & & & 5 & 12 & 27 & \\
\hline \multirow[t]{4}{*}{0.025} & $H W$ & $N$ & $2.5 \pm 1.7$ & $0.3 \pm 0.6$ & $\begin{array}{c}0.3 \pm 0.8 \\
\text { NS }\end{array}$ & $2.0 \pm 1.1$ \\
\hline & & $d w$ & $2.3 \pm 1.0$ & $1.0 \pm 1.1$ & $0.2 \pm 0.5$ & $2.8 \pm 1.9$ \\
\hline & $L W$ & $N$ & $5.2 \pm 2.3$ & $2.2 \pm 2.0$ & $0.3 \pm 0.5$ & $2.8 \pm 1.3$ \\
\hline & & $d w$ & $7.0 \pm 3.3$ & $2.3 \pm 0.9$ & $2.0 \pm 0.0$ & $6.3 \pm 2.7$ \\
\hline \multirow[t]{6}{*}{0.25} & $H W$ & $N$ & $3.2 \pm 2.0$ & $2.1 \pm 1.4$ & $0.9 \pm 1.1$ & $4.8 \pm 1.2$ \\
\hline & & $d w$ & $6.9 \pm 1.7$ & $4.5 \pm 1.1$ & $1.6 \pm 0.6$ & $5.6 \pm 1.5$ \\
\hline & $L W$ & $N$ & $9.2 \pm 3.6$ & $\begin{array}{c}6.1 \pm 3.8 \\
\mathrm{NS}\end{array}$ & $2.7 \pm 2.0$ & $4.8 \pm 1.2$ \\
\hline & & $d w$ & $11.4 \pm 2.8$ & $5.3 \pm 2.4$ & $3.8 \pm 2.0$ & $6.8 \pm 2.1$ \\
\hline & $H A^{(1)}$ & $N$ & $12.4 \pm 1.8$ & $6.2 \pm 2.1$ & $2.7 \pm 0.8$ & $5.8 \pm 2.1$ \\
\hline & $L A^{(1)}$ & $N$ & $4.0 \pm 2.2$ & $1.6 \pm 2.6$ & $1.0 \pm 1.1$ & $3.2 \pm 1.5$ \\
\hline \multirow[t]{4}{*}{25} & $H W$ & $N$ & $12.8 \pm 2.2$ & $6.6 \pm 2.0$ & $3.3 \pm 2.2$ & $5.3 \pm 1.8$ \\
\hline & & $d w$ & $13.6 \pm 1.3$ & $9.2 \pm 1.7$ & $4.0 \pm 2.6$ & $7.0 \pm 1.0$ \\
\hline & $L W$ & $N$ & $13.7 \pm 0.5$ & $\begin{array}{c}8.1 \pm 1.9 \\
\text { NS }\end{array}$ & $4.8 \pm 1.6$ & $6.7 \pm 1.8$ \\
\hline & & $d w$ & $13.6 \pm 0.5$ & $8.1 \pm 1.8$ & $4.8 \pm 1.7$ & $7.0 \pm 1.8$ \\
\hline
\end{tabular}

${ }^{*} \mathrm{P}<0.05,{ }^{* *} \mathrm{P}<0.01$, NS no significant difference $(\mathrm{P}>0.05)$.

$L=$ line, $G=$ genotype.

(1) Reference populations, selected for high (HA) or low (LA) antibody production to SRBC. Boxes indicate significant line $\times$ genotype interactions. See table 1 for line and genotype differences.

When chicks were injected with $0.25 \%$ SRBC, antibody titers five days PPI were higher for $L W$ than $H W$, and dwarf than normal chicks, with no line $\times$ genotype interaction (table 1). Twelve days PPI the interaction was significant, with dwarfs having higher titers than normals in line $H W$ but not $L W$ (table 2). By 27 days PPI, titers were higher for $L W$ than for $H W$ chicks (table 1), with no effect of alleles at the dwarf locus on residual titers. When given the booster, however, the background genome had no effect on secondary response while titers were higher for dwarf than nondwarf chicks.

For chicks inoculated with a suspension of $25 \%$ SRBC, there were no differences among genetic populations for titers 5 and 27 days PPI or 3 days PSI (table 1). Twelve days PPI a line $\times$ genotype interaction existed with dwarfs having higher titers than normals in line $H W$ but not line $L W$ (table 2). This pattern was due, in part, to a greater decrease in titers from 5 to 12 days for $H W N$ chicks than for those from the other populations. 
In Experiment II, titers at 36 and 71 days of age were different so analyses were made within ages. Interactions of line $\times$ genotype were not significant and hence marginal means are presented. At 36 days of age (5 days PPI) titers were higher for dwarf than normal chicks $(30.1 \pm 1.9 v s 2.2 \pm 1.8)$, and for line $L W$ than $H W$ chicks $(3.5 \pm 1.8 v s 2.0 \pm 1.7)$. At 71 days of age (5 days PPI) the pattern was similar, with titers of $6.7 \pm 3.1$ and $3.7 \pm 2.9$ for $L W$ and $H W$ chicks, respectively and $5.6 \pm 3.0$ for dwarfs and $4.3 \pm 3.0$ for normal chicks.

\section{B. Thyroid hormones}

Age effects (36 vs 71 days) and interactions of age with line and with genotype were significant for thyroid hormones and $T_{3} / T_{4}$ ratios. Accordingly, subsequent analyses were conducted within ages for these three traits. At the younger age there was no line $\times$ genotype interaction for plasma concentrations of $T_{3}(\mathrm{ng} / \mathrm{ml})$, nor any difference between $H W(1.38 \pm 0.47)$ and $L W(1.41 \pm 0.54)$ chicks. Normal chicks had higher $T_{3}$ concentrations $(1.65 \pm 0.40)$ than dwarfs $(1.02 \pm 0.36)$. At 71 days of age, the interaction was significant because the difference between dwarfs and normals was significant in line $L W$ but not in line $H W$ (table 3 ). Line $\times$ genotype interactions were

TABLE 3

Means and standard deviations of plasma concentrations ( $\mathrm{ng} / \mathrm{ml})$ of $T_{3}$ and $T_{4}$ for normal $(\mathrm{N})$ and dwarf $(\mathrm{dw})$ genotypes within the high (HW) and low (LW) weight lines at 36 and 71 days of age

\begin{tabular}{|c|c|c|c|c|}
\hline & \multirow{2}{*}{ Line } & \multirow{2}{*}{ G } & \multicolumn{2}{|c|}{ Age (days) } \\
\hline & & & 36 & 71 \\
\hline $\mathrm{T}_{3}$ & $\begin{array}{l}H W \\
L W\end{array}$ & $\begin{array}{l}N \\
d w \\
N \\
d w\end{array}$ & $\begin{array}{c}1.66 \pm 0.33 \\
* * \\
1.07 \pm 0.39 \\
1.63 \pm 0.48 \\
* * \\
0.86 \pm 0.16\end{array}$ & $\begin{array}{c}1.74 \pm 0.69 \\
\text { NS } \\
1.49 \pm 0.75 \\
2.56 \pm 0.96 \\
* * \\
1.18 \pm 0.62 \\
\end{array}$ \\
\hline $\mathrm{T}_{4}$ & $\begin{array}{l}H W \\
L W\end{array}$ & $\begin{array}{c}N \\
d w \\
N \\
d w\end{array}$ & $\begin{array}{c}8.79 \pm 2.53 \\
\text { NS } \\
8.95 \pm 2.29 \\
7.18 \pm 2.75 \\
* * \\
10.58 \pm 2.84\end{array}$ & $\begin{array}{c}14.71 \pm 3.97 \\
* \\
12.66 \pm 3.45 \\
11.62 \pm 3.70 \\
* * \\
17.90 \pm 2.76 \\
\end{array}$ \\
\hline $\mathrm{T}_{3} / \mathrm{T}_{4}$ & $\begin{array}{l}H W \\
L W\end{array}$ & $\begin{array}{c}N \\
d w \\
N \\
d w\end{array}$ & $\begin{array}{c}0.21 \pm 0.10 \\
* * \\
0.12 \pm 0.04 \\
0.29 \pm 0.23 \\
* * \\
0.09 \pm 0.02\end{array}$ & $\begin{array}{c}0.13 \pm 0.06 \\
\text { NS } \\
0.14 \pm 0.10 \\
0.25 \pm 0.16 \\
* * \\
0.07 \pm 0.03\end{array}$ \\
\hline
\end{tabular}

${ }^{*} \mathrm{P}<0.05,{ }^{* *} \mathrm{P}<0.01$, NS no significant difference $(\mathrm{P}>0.05)$.

$G=$ genotype.

Boxes indicate significant line $\times$ genotype interactions. 
significant for plasma $T_{4}$ concentrations at both ages. At the younger age, $T_{4}$ was consistently higher for dwarf than normal chicks in line $L W$ while there was no difference in line $H W$. In older chicks there was a crossover interaction with the higher values for normals in line $H W$ and for dwarfs in line $L W$.

At 36 days of age there was no line $\times$ genotype interaction for $T_{3} / T_{4}$ ratios. There was no difference between lines; however, ratios were lower for dwarf than normal chicks. In older chicks there was a line $\times$ genotype interaction for $\mathrm{T}_{3} / \mathrm{T}_{4}$ ratios (table $3)$. In line $L W$ ratios were consistently greater for normal than dwarf chicks, while in line $H W$ there was no difference between dwarf and normal chicks.

\section{Discussion}

Differences between lines in SRBC antibody response were dose dependent, with $L W$ chicks having higher titers than $H W$ chicks at the intermediate and lower doses. These line differences were also observed in previous experiments (REDDY et al., 1975 ; Mauldin et al., 1978 ; Marsteller et al., 1980). The lack of line differences at the higher dose of antigen was consistent with the masking of genetic differences in antibody response by using either high or low dosages of antigen (UBOSI et al., $1985 \mathrm{~b}$ ).

Within lines, generally dwarfs had higher peak SRBC titers than nondwarfs at the intermediate dose, while at other doses there were no differences between genotypes. Previous researchers reported similar results in line $H W$, but line $L W$ dwarfs had lower titers than normals (REDDY et al., 1975 ; MAULdiN et al., 1978 ; MARSTELler et al., 1980). This change in line $L W$ may be due to continued selection for low body weight in $L W N$ but not in $L W D$ in the intervening generations, which resulted in a shift where during early ages dwarfs are no longer smaller than normal chicks in line $L W$ (ZELENKA et al., 1986). MARSH (1983) showed that differences between dwarf and nondwarf Leghorns could be masked using high doses of SRBC.

The pattern of a difference in $\mathrm{T}_{3}$ and $\mathrm{T}_{4}$ concentrations at an older but not a younger age between $H W N$ and $L W N$ chicks is consistent with previous results for these populations (NIR et al., 1987). Because $T_{3}$ is considered to be the metabolically active thyroid hormone (see review in $\mathrm{McN}_{\mathrm{ABB}}$, 1987), the lower plasma $\mathrm{T}_{3}$ concentrations of $H W N$ chicks at the older age may indicate a mild functionally hypothyroid condition in line $H W$. Plasma $\mathrm{T}_{4}$ concentrations, however, were not decreased in $H W$ chicks, suggesting that such hypothyroidism is a peripheral phenomenon, not one of thyroid gland origin.

Thyroid hormone concentrations of dwarf and normal chicks differed in lines $H W$ and $L W$. Plasma $\mathrm{T}_{4}$ of dwarf chicks was suggestive of "normal " activity in the thyroid gland since no reduction in $\mathrm{T}_{4}$ was seen relative to nondwarf chicks. Differences between groups in plasma $T_{4}$, which is considered to be a prohormone, are probably less important than differences in $\mathrm{T}_{3}$.

Lower plasma $T_{3}$ and $T_{3} / T_{4}$ ratios, and elevated $T_{4}$ concentrations of dwarfs relative to nondwarfs in line $L W$ are suggestive of decreased peripheral deiodination in $L W$ dwarfs. These results are consistent with those showing lower $\mathrm{T}_{3}$ and higher $\mathrm{T}_{4}$ concentrations in dwarf white Leghorn chickens (SCANES et al., 1983; MARSH et al., 
$1984 a ; 1984 b$ ) that resulted from decreased peripheral deiodination of $T_{4}$ to $T_{3}$ (SCANES et al., 1983). A similar pattern of hormone concentrations exists in meat-type stocks (MAY \& MARKS, 1983 ; LAUTERIO et al., 1986), although exceptions have been noted (Callahan \& Parsons, 1986). In line $H W$ there was less difference between dwarfs and normals for thyroid hormone concentrations, and reduced peripheral deiodination did not appear to be a factor at the older age. Thus, the expression of allele $d w$ is influenced by the background genome, an observation noted for other traits (MAULDiN et al., 1978 ; MÉRAT, 1982 ; LilbuRn et al., 1986 a).

Previous studies using both Leghorns (HuYBrechts et al., 1986) and meat-type chickens (LILBURN et al., $1986 a$ ) suggest that plasma $T_{3}$ and $T_{4}$ concentrations of dwarfs differ from normals only at younger ages, with the difference in $T_{3}$ concentrations persisting longer. Although we found no evidence of age-related patterns in plasma thyroid hormones in line $L W$, the picture for line $H W$ was more complex and suggested age related changes. In line $H W$ there was little change in plasma $\mathrm{T}_{3}$ between 36 and 71 days of age in normal chicks, while in dwarfs the concomitant increase in plasma $T_{3}$ to 71 days of age overcame the earlier difference between genotypes.

A consistent relationship between plasma thyroid hormone concentrations and antibody response to SRBC was not apparent in these populations. Since previous researchers obtained results opposite from ours in antibody response to SRBC by dwarf chickens (MARSH, 1983), but plasma $\mathrm{T}_{3}$ concentrations were similar to ours, plasma $\mathrm{T}_{3}$ is probably not the causative factor in differences in antibody response to SRBC between dwarf and nondwarf chickens. Because the $d w$ allele had similar effects on titers of both $H W$ and $L W$ chicks but had markedly different effects on plasma $\mathrm{T}_{4}$ levels, $\mathrm{T}_{4}$ probably does not directly affect immune response to SRBC. This conclusion also was reached by MARSH et al. (1984 b) from experiments supplementing dwarfs with $T_{4}$. Although feed supplementation with $T_{3}$ or $T_{4}$ increased thymic weights and serum levels of $T_{3}$ and $T_{4}$ of both normal and dwarf chicks, there was no accompanying increase in antibody titers to SRBC (MARSH et al., $1984 a ; 1984 b$ ). While bursa weights of normal chicks fed $T_{3}$ or $T_{4}$ were increased, $T_{4}$ and $T_{3}$ supplementation to dwarfs increased and decreased bursa weight, respectively (MARSH et al., $1984 a$; $1984 \mathrm{~b}$ ). The lack of a correlated response in SRBC titers is not surprising because the relationship of SRBC antibody levels with thymic and bursal weight has been equivocal (Yамамото \& Glick, 1982 ; Ubosi et al., 1985 a).

Antibody responses to SRBC in trials where hypothyroidism was induced experimentally by feeding thiouracil have also been mixed. In some cases there were no differences between thiouracil-fed and control chicks (MASHALY et al., 1983 ; MARTIN et al., 1987). In others, those fed thiouracil had higher (ScOTT et al., 1985) or lower (YAM et al., 1981) titers than controls. Thus, feeding experiments as well as those using populations known to differ in immunoresponsiveness and thyroid hormone concentrations suggest that a direct relationship between thyroid hormones and antibody response to SRBC is unlikely. This may be due to interactions of plasma thyroid hormone concentrations with factors such as age, dose and source of antigen, as well as the previous life history of the individuals and populations.

Received November 12, 1987. Accepted February 15, 1988. 


\section{Acknowledgements}

This research was supported, in part, by BARD project \# I-938-85.

\section{References}

Callahan M.B., Parsons A.H., 1986. Thyroid hormone concentrations in selected lines of normal and sex-linked dwarf (SLD) broiler chickens. Poult. Sci., 65 (suppl. 1), 19 (abstr.)

Dunnington E.A., Siegel P.B., 1985. Long-term selection for 8-week body weight in chickens direct and correlated responses. Theor. Appl. Genet., 71, 305-313.

GuICK B., 1984. Interrelation of the avian immune and neuroendocrine systems. J. Exp. Zool., 232, 671-682.

Huybrechts L.M., Kuhn E.R., Mérat P., Decuypere E., Michels H., Tixier M., 1986. Endocrinological effects of the sex linked dwarf gene. 1. Effects on growth and plasma thyroid hormone concentration. In: 7th European Poultry Conference of the World's Poultry Science Association, 24-28 August, 1986, vol. 2, Physiology and Behavior Section 4, 950-954, World's Poultry Science Association, Paris.

Lauterio T.J., Decuypere E., Scanes C.G., 1986. Growth, protein synthesis and plasma concentrations of growth hormone, thyroxine, and triiodothyronine in dwarf, control and growthselected strains of broiler-type domestic fowl. Comp. Biochem. Physiol., 83 A, 627-632.

Lilburn M.S., Ngiam-Rilling K., Leung F.C., Smith J.H., $1986 a$. The relationship between age and genotype and the growth of commercial meat strain chickens. Proc. Soc. Exp. Biol. Med., 182, 328-335.

Lilburn M.S., Rilling K., Mack F., Mills E.O., Smith J.H., 1986 . Growth and development of broiler breeders. 1. Effect of early plane of nutrition and growth rate. Poult. Sci., 65, 1070-1075.

MARSH J.A., 1983. Assessment of antibody production in sex-linked and autosomal dwarf chickens. Dev. Comp. Immunol., 7, 535-544.

Marsh J.A., Gause W.C., Sandhu S., Scanes C.G., $1984 a$. Enhanced growth and immune development in dwarf chickens treated with mammalian growth hormone and thyroxine. Proc. Soc. Exp. Biol. Med., 175, 351-360.

Marsh J.A., Lauterio T.J., Scanes C.G., $1984 \mathrm{~b}$. Effects of triiodothyronine treatments on body and organ growth and the development of immune function in dwarf chickens. Proc. Soc. Exp. Biol. Med., 177, 82-91.

Marsteller F.A., Gross W.B., Siegel P.B., 1980. Antibody production and Escherichia coli resistance in socially stable flocks of dwarf and nondwarf chickens. Poult. Sci., 59, 1947-1948.

Martin A., McNabi F.M.A., Siegel P.B., 1987. Thiouracil and antibody titers of chickens from lines divergently selected for antibody response to sheep erythrocytes. Poult. Sci., 66 (suppl. 1), 139 (abstr.).

Mashaly M.M., Youtz S.L., Wideman R.F., 1983. Hypothyroidism and antibody production in immature male chickens. Immunol. Commun., 12, 551-563.

Mauldin J.M., Siegel P.B., Gross W.B., 1978. Dwarfism in diverse genetic backgrounds. 2. Behavior and disease resistance. Poult. Sci., 57, 1488-1492.

MaY J.D., Marks H.L., 1983. Thyroid activity of selected, nonselected, and dwarf broiler lines. Poult. Sci., 62, 1721-1724.

McNabB F.M.A., 1987. Comparative thyroid development in precocial Japanese quail and altricial Ring doves. J. Exp. Zool., 240 (suppl. 1), 281-290.

McNabb F.M.A., Hughes T.E., 1983. The role of serum binding proteins in determining free thyroid hormone concentrations during development in quail. Endocrinol., 113, 957-963. 
Mérat P., 1982. Quantitative aspects of poultry breeding. In : 2nd World Congress on Genetics Applied to Livestock Production, 4-8 October, 1982, vol. 5, Poultry Genetics and Breeding Section E, 727-741, Editorial Garsi, Madrid.

Nir I., Harvey S., Cherry J.A., Dunnington E.A., Klandorf H., Siegel P.B., 1987. Growthassociated traits in parental and $F_{1}$ populations of chickens under different feeding programs. 4. Growth and thyroid hormones. Poult. Sci., 66, 32-37.

Reddy P.R.K., Gross W.B., Van Krey H.P., Siegel P.B., 1975. Blood parameters of dwarf and normal pullets from growth selected lines before and after Escherichia coli challenge. Poult. Sci., 54, 674-681.

Scanes C.G., Marsh J.A., Decuypere E., Rudas P., 1983. Abnormalities in the plasma concentrations of thyroxine, triiodothyronine, and growth hormone in sex-linked dwarf and autosomal dwarf White Leghorn domestic fowl. J. Endocrinol., 97, 127-135.

SCOTT T., VAN DER ZiJPP A., GLICK B., 1985. Effect of thiouracil- induced hypothyroidism on the humoral immunity of New Hampshire chickens. Poult. Sci., 64, 2211-2217.

Siegel P.B., 1962. Selection for body weight at eight weeks of age. 1. Short term response and heritabilities. Poult. Sci., 41, 954-962.

Siegel P.B., Gross W.B., 1980. Production and persistence of antibody in chickens to sheep erythrocytes. 1. Directional selection. Poult. Sci., 59, 1-5.

Siegel P.B., Gross W.B., Cherry J.A., 1982. Correlated responses of chickens to selection for production of antibody to sheep erythrocytes. Anim. Blood Groups Biochem. Genet., 13, 291297.

Ubosi C.O., Gross W.B., Siegel P.B., 1985 a. Divergent selection of chickens for antibody production to sheep erythrocytes : age effects in parental lines and their crosses. Avian Dis., 29, $150-158$.

Ubosi C.O., Dunnington E.A., Gross W.B., Siegel P.B., 1985 b. Divergent selection of chickens for antibody response to sheep erythrocytes : kinetics of primary and secondary immunizations. Avian Dis., 29, 347-355.

Van der Zijpp A.J., Kreukniet M.B., Nieuwland M.G.B., 1987. Responses to selection for high and low antibody production. Poult. Sci., 66 (suppl. 1), 188 (abstr.).

Wegmann T.G., Smithies O., 1966. A simple hemagglutination system requiring small amounts of red cells and antibodies. Transfusion, 6, 67-73.

Yam D., Heller D., SinaPir N., 1981. The effect of the thyroidal state on the immunological state of the chicken. Dev. Comp. Immunol., 5, 483-490.

Yамамото Y., Glick B., 1982. A comparison of the immune response between two lines of chickens selected for differences in the weight of the Bursa of Fabricius. Poult. Sci., 61, 21292132.

Zelenka D.J., Dunnington E.A., Siegel P.B., 1986. Growth to sexual maturity of dwarf and nondwarf White Rock chickens divergently selected for juvenile body weight. Theor. Appl. Genet., 73, 61-65. 